\title{
Microfinance Commercialization and Mission Drift
}
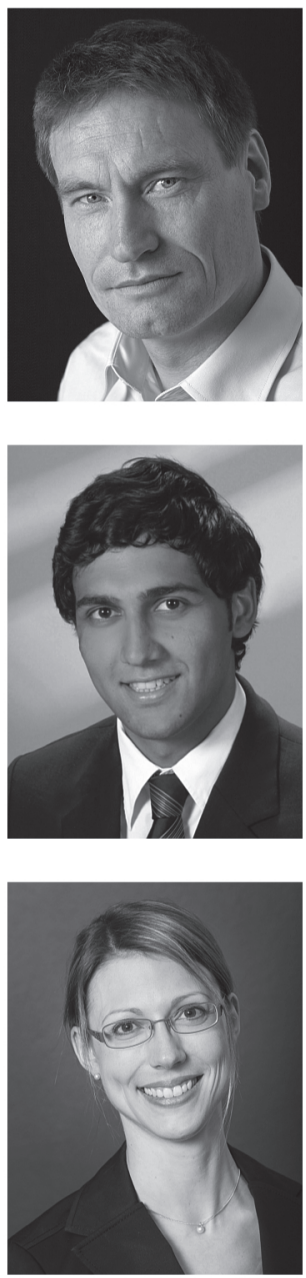
Literatur zu Kommerzialisierung und Mission Drift, und die Ergebnisse zeigen, dass die
Sorge um einen Mission Drift in der Mikrofinanzbranche unbegründet erscheint. Wir ge-
hen zudem auf die Ergebnisse einer neuen Studie ein, in der wir die Analyse des Mission
Drifts zu erweitern suchen, indem wir den Einfluss kommerzieller Mikrofinanzbanken auf
den Zugang zu Bankkonten mit jenem von normalen Retailbanken vergleichen. Wir fin-
den, dass kommerzielle Mikrofinanzbanken den Zugang zu Finanzdienstleistungen tat-
sächlich ausweiten, was ihre Unterstützung durch bi- und multilaterale Geber gerechtfer-
tigt erscheinen lässt. Literatur zu Kommerzialisierung und Mission Drift, und die Ergebnisse zeigen, dass die
Sorge um einen Mission Drift in der Mikrofinanzbranche unbegründet erscheint. Wir ge-
hen zudem auf die Ergebnisse einer neuen Studie ein, in der wir die Analyse des Mission
Drifts zu erweitern suchen, indem wir den Einfluss kommerzieller Mikrofinanzbanken auf
den Zugang zu Bankkonten mit jenem von normalen Retailbanken vergleichen. Wir fin-
den, dass kommerzielle Mikrofinanzbanken den Zugang zu Finanzdienstleistungen tat-
sächlich ausweiten, was ihre Unterstützung durch bi- und multilaterale Geber gerechtfer-
tigt erscheinen lässt. Literatur zu Kommerzialisierung und Mission Drift, und die Ergebnisse zeigen, dass die
Sorge um einen Mission Drift in der Mikrofinanzbranche unbegründet erscheint. Wir ge-
hen zudem auf die Ergebnisse einer neuen Studie ein, in der wir die Analyse des Mission
Drifts zu erweitern suchen, indem wir den Einfluss kommerzieller Mikrofinanzbanken auf
den Zugang zu Bankkonten mit jenem von normalen Retailbanken vergleichen. Wir fin-
den, dass kommerzielle Mikrofinanzbanken den Zugang zu Finanzdienstleistungen tat-
sächlich ausweiten, was ihre Unterstützung durch bi- und multilaterale Geber gerechtfer-
tigt erscheinen lässt. Literatur zu Kommerzialisierung und Mission Drift, und die Ergebnisse zeigen, dass die
Sorge um einen Mission Drift in der Mikrofinanzbranche unbegründet erscheint. Wir ge-
hen zudem auf die Ergebnisse einer neuen Studie ein, in der wir die Analyse des Mission
Drifts zu erweitern suchen, indem wir den Einfluss kommerzieller Mikrofinanzbanken auf
den Zugang zu Bankkonten mit jenem von normalen Retailbanken vergleichen. Wir fin-
den, dass kommerzielle Mikrofinanzbanken den Zugang zu Finanzdienstleistungen tat-
sächlich ausweiten, was ihre Unterstützung durch bi- und multilaterale Geber gerechtfer-
tigt erscheinen lässt. Literatur zu Kommerzialisierung und Mission Drift, und die Ergebnisse zeigen, dass die
Sorge um einen Mission Drift in der Mikrofinanzbranche unbegründet erscheint. Wir ge-
hen zudem auf die Ergebnisse einer neuen Studie ein, in der wir die Analyse des Mission
Drifts zu erweitern suchen, indem wir den Einfluss kommerzieller Mikrofinanzbanken auf
den Zugang zu Bankkonten mit jenem von normalen Retailbanken vergleichen. Wir fin-
den, dass kommerzielle Mikrofinanzbanken den Zugang zu Finanzdienstleistungen tat-
sächlich ausweiten, was ihre Unterstützung durch bi- und multilaterale Geber gerechtfer-
tigt erscheinen lässt. Literatur zu Kommerzialisierung und Mission Drift, und die Ergebnisse zeigen, dass die
Sorge um einen Mission Drift in der Mikrofinanzbranche unbegründet erscheint. Wir ge-
hen zudem auf die Ergebnisse einer neuen Studie ein, in der wir die Analyse des Mission
Drifts zu erweitern suchen, indem wir den Einfluss kommerzieller Mikrofinanzbanken auf
den Zugang zu Bankkonten mit jenem von normalen Retailbanken vergleichen. Wir fin-
den, dass kommerzielle Mikrofinanzbanken den Zugang zu Finanzdienstleistungen tat-
sächlich ausweiten, was ihre Unterstützung durch bi- und multilaterale Geber gerechtfer-
tigt erscheinen lässt. Literatur zu Kommerzialisierung und Mission Drift, und die Ergebnisse zeigen, dass die
Sorge um einen Mission Drift in der Mikrofinanzbranche unbegründet erscheint. Wir ge-
hen zudem auf die Ergebnisse einer neuen Studie ein, in der wir die Analyse des Mission
Drifts zu erweitern suchen, indem wir den Einfluss kommerzieller Mikrofinanzbanken auf
den Zugang zu Bankkonten mit jenem von normalen Retailbanken vergleichen. Wir fin-
den, dass kommerzielle Mikrofinanzbanken den Zugang zu Finanzdienstleistungen tat-
sächlich ausweiten, was ihre Unterstützung durch bi- und multilaterale Geber gerechtfer-
tigt erscheinen lässt. Literatur zu Kommerzialisierung und Mission Drift, und die Ergebnisse zeigen, dass die
Sorge um einen Mission Drift in der Mikrofinanzbranche unbegründet erscheint. Wir ge-
hen zudem auf die Ergebnisse einer neuen Studie ein, in der wir die Analyse des Mission
Drifts zu erweitern suchen, indem wir den Einfluss kommerzieller Mikrofinanzbanken auf
den Zugang zu Bankkonten mit jenem von normalen Retailbanken vergleichen. Wir fin-
den, dass kommerzielle Mikrofinanzbanken den Zugang zu Finanzdienstleistungen tat-
sächlich ausweiten, was ihre Unterstützung durch bi- und multilaterale Geber gerechtfer-
tigt erscheinen lässt.

\section{Martin Brown, Benjamin Guin and Karolin Kirschen- mann}

Access to finance, microfinance, commercialization, mission drift Zugang zu Finanzdienstleistungen, Mikrofinanzierung, Kommerzialisierung, Mission Drift

Policy makers and practitioners agree that the scaling up of microfinance requires financial sustainability in the industry and access to commercial capital markets. At the same time they worry that the commercialization of microfinance may lead to a mission drift: Microfinance institutions (MFIs) may abandon their focus on poor, rural, female borrowers and orientate themselves towards more profitable clients. In this contribution we review the empirical evidence on commercialization and mission drift in microfinance, and the evidence is that fears of a mission drift in the industry do not seem warranted. Furthermore, we report on a recent study in which we attempt to broaden the analysis of mission drift, by comparing the impact of commercial microfinance banks as opposed to ordinary retail banks on household access to and use of bank accounts. We find that commercial microfinance banks do expand the frontier of finance providing further justification to their support by bilateral and multilateral donors.

Politiker und Praktiker stimmen darin überein, dass es für eine Ausweitung der Mikrofinanzbranche finanzieller Nachhaltigkeit und des Zugangs zu kommerziellen Kapitalmärkten bedarf. Jedoch sorgen sie sich gleichzeitig, dass solch eine Kommerzialisierung zu einem Mission Drift fübren könnte: Mikrofinanzinstitutionen (MFI) könnten ibren Fokus auf arme, ländliche und weibliche Kreditnehmer aufgeben und sich profitableren Kunden zuwenden. In diesem Beitrag geben wir einen Überblick über die bestehende empirische 


\section{Introduction}

"Now [microfinance] is in great danger of being how well the investors and the microfinance institutions are doing and not about ending poverty."

(Sam Daley-Harris, then Director of Microcredit Summit Campaign, 2008)

The Initial Public Offering of Banco Compartamos in Mexico in April 2007 set off an intensive debate among practitioners, policymakers and academics whether the microfinance sector was now on its way to become profit-orientated business (New York Times 2008). With donor money being limited and global demand for microloans estimated to be ten times as high as the amount already lent (Deutsche Bank Research 2007), the industry has long discussed suitable ways to tap capital markets. While the need for additional funding sources achieves unanimous acclaim, the opinions differ tremendously when it comes to the question how far a potential commercialization of microfinance should go.

Commercialization in this context means that Microfinance Institutions (MFIs) apply commercial principles in their operations and attempt to be financially self-sufficient (e.g., Charitonenko et al. 2004). The main concern about a move down the commercialization road is that it might lead to a mission drift implying that for-profit MFIs become less focused on their initial target group (typically poor and female customers) and switch their attention to customers that are less credit-constrained (Mersland/Strom 2010).

Commercialization critics claim that profit-orientated MFIs such as Banco Compartamos intend to benefit their investors but not their borrowers. Mohammad Yunus, founder of the Grameen Bank and winner of the 2006 Nobel Peace Prize, argues that profit-orientated MFIs would raise interest rates and engage in aggressive marketing and loan collection. As a result, borrowers whom microcredit was supposed to help overcome poverty could even be harmed (Yunus 2011). These arguments represent the traditional poverty lending approach: the primary goal is to reach the poor, and especially the poorest of the poor, with the help of credit extended by donor-subsidized MFIs (Robinson 2001). It implicitly assumes that MFIs typically face a trade-off between financial sustainability, i.e. the ability to cover the cost of lending out of the income generated from lending, and outreach, i.e. focusing the lending activities on the poor that otherwise have no access to credit (Hermes et al. 2011).

Supporters of the financial system perspective (Robinson 2001), in contrast, argue that commercialization is actually beneficial for the potential borrowers: commercialization ensures financial sustainability which guarantees large-scale outreach to poor customers in the long run (Hermes/Lensink 2011). Commercial microfinance banks may also receive support from international donors and development banks through subsidized credit lines and equity participation. This support is rationalized by the conjecture that microfinance banks generate positive externalities by offering financial services to small firms and households which would not be served by "ordinary" retail banks. Whether commercial microfinance providers can actually expand the frontier of finance has, however, been questioned by practitioners and academics (e.g. Christen 2001).

In this paper, we first review the empirical evidence on commercialization and mission drift. The existing literature typically compares the outreach of MFIs, as proxied by the average loan size and the socioeconomic characteristics of borrowers, to identify mission drift and examines whether changes in outreach are related to commercialization, as proxied by profitability, ownership or funding structure. These studies do not provide strong 
evidence for a mission drift in microfinance. While MFIs do seem to move more upmarket as they become more mature, aggregate trends do not point to a substantial reduction in social performance of the microfinance industry as a whole. Moreover, fears of a fundamental tension between the financial and social performance at the level of individual MFIs do not seem warranted.

In the second part of the paper we address two key gaps in the existing empirical literature on mission drift: First, continued public support to commercial microfinance banks can only be justified if they provide social benefits above and beyond those provided by ordinary commercial retail banks. As a consequence, the social performance of commercial MFIs should not only be compared to that of non-commercial MFIs, but also to that of ordinary retail banks. Second, while academics and practitioners argue that access to saving and payment services is equally important for poor households as access to credit, the social performance of MFIs has been predominantly measured in terms of their lending activity. A comprehensive analysis of mission drift should take into account the range of financial services which MFIs provide to the poor, the accessibility of these services, e.g. the number of branches, ATMs and other points of sale, as well as the number and socioeconomic characteristics of households which use these services.

We present results of a recent study using household-level survey data from South-East Europe in 2006 and 2010 to shed light on whether microfinance banks expand access to finance as compared to ordinary retail banks. Our results suggest that this is the case. The impact of microfinance banks on expanding the frontier of finance is twofold: First, they are more likely to locate in regions with larger shares of low-income and informally employed households. Second, if, in addition to a retail bank, they do locate in a region the number of low-income and informal-income households with a bank account increases.

The remainder of the paper is organized as follows. In section 2 we provide an overview of the existing literature on commercialization and mission drift. Section 3 describes the data and methodology we use in our analysis, while section 4 presents the results. Section 5 concludes.

\section{Review of the existing literature}

\subsection{Commercialization and MFIs' financial and social performance}

In this section we review case studies and cross-sectional studies which examine the impact the commercialization process has on MFIs' financial performance (measured by operating revenues, cost-efficiency, return on assets, or loan portfolio quality) and social performance (measured by the proportion of female borrowers, average loan sizes or the focus on rural vs. urban markets).

Mersland/Strom (2010) examine a dataset that contains rated MFIs in 74 countries in the period from 1998 to 2008 to analyze whether the MFI sector as a whole has experienced a mission drift. As proxies for mission drift they employ the average loan size as well as the MFI's proportion of lending to urban, to male and to individual borrowers. Surprisingly, the evidence for a mission drift in the industry as a whole is rather weak: Neither average loan sizes nor the proportion of lending to urban, to male as well as to individual borrowers seems to have increased over time. However, their result that average loan sizes increase with increased average profit and cost indicates that mission drift may occur if MFIs aim for better profitability. But this effect can be offset by better cost 
efficiency. Hermes et al. (2011) analyze whether there is actually a trade-off between MFIs' cost efficiency and their outreach to the poor. Using a dataset that covers 435 MFIs and 1,318 observations over a period of 11 years (1997-2007), they find evidence that outreach is negatively related to the efficiency of MFIs. Similarly to Mersland/Strom (2010) they conclude that increased efficiency might only be achieved if MFIs focus less on the poor, i.e. if mission drift takes place.

Tchakoute-Tchuigoua (2010) examines the impact of profit-orientation on financial performance using a comprehensive dataset covering 202 MFIs in the period from 2001 to 2006. He finds that the financial performance of profit-orientated MFIs is better than that of non-profit seeking MFIs with respect to their portfolio quality but that there is no significant difference in profitability. He also finds that profit-orientated MFIs are more socially efficient than non-profit seeking MFIs both in terms of breadth of outreach (measured by the number of active borrowers) and depth of outreach (measured by the average loan balance per borrower over the gross national income per capita).

Roberts (forthcoming) analyzes the relationship between adopting a for-profit legal form and lending rates. Using data on reports of 358 MFIs in 2009, he finds that a stronger for-profit orientation corresponds with higher interest rates for MFI clients. However, there is no evidence that this contributes to greater profitability and therefore sustainability because the stronger profit orientation is also associated with higher MFI costs. Whether an increase of interest rates does have an effect on the demand for credit by microlenders is analyzed by Karlan/Zinman (2008). Conducting randomized trials with a major, for-profit consumer microlender in South Africa, they test the hypothesis of price inelastic demand for consumer credit. Using a sample that includes former borrowers of the institution, they find evidence for price inelastic demand for a wide range of prices. Similarly, Dehejia et al. (2012) analyze unexpected price changes at SafeSave, a microfinance organization operating in the slums of Dhaka (Bangladesh), and find relatively low interest rate elasticities.

The privatization of Tanzania's National Bank of Commerce, which was split into the "new" National Bank of Commerce and the National Microfinance Bank, is analyzed by Cull/Spreng (2011). They estimate the impact this privatization has on banks' profitability and the quality of their credit portfolios. Using quarterly balance sheet and income statement data between December 1998 and December 2006, they find that the "new" National Bank of Commerce's profitability and portfolio quality improved although credit growth was slow. Regarding the National Microfinance Bank, there is evidence that profitability has since improved and lending has slowly grown, while the share of non-performing loans has remained low. Similarly, Clarke et al. (2009) analyze the privatization of Uganda Commercial Bank (UCB). Using quarterly data from 1996 to 2005, they find that both profitability and the rate of credit growth increased to par with other Ugandan banks. At the same time, there is no evidence that outreach has declined - to the contrary, the results rather indicate that it might have expanded.

Mersland et al. (2011) analyze whether international influence affects the financial and social performance of MFIs. They distinguish between four sources of such internationalization effects (international initiator, international directorship, international debt, and international affiliation/networks) and exploit a dataset of 379 MFIs in 73 developing countries between 2001 and 2008. They find that internationalization of MFIs does not enhance financial performance or financial self-sufficiency: while having an international 
initiator significantly increases return on assets and operational self-sufficiency, the effect vanishes once subsidies are taken into account. In contrast, the internationalization of an MFI seems to significantly affect its social performance. All aspects of internationalization increase the MFI's bias in preferring women as customers. Yet, in case of outreach to rural areas, the different dimensions of internationalization have conflicting results: While receiving international subsidized debt seems to increase outreach to the rural market, being member of an international network and having an international initiator tend to reduce the MFI's presence in the rural market.

\subsection{Factors impacting on the relation between profitability and outreach}

Cull et al. (2007) find that the relationship between profitability and outreach depends on the lending technology of the MFI. Using annual data on 124 MFIs in 49 developing countries from 1999 to 2002, they analyze whether MFIs tend to move away from serving poorer clients as they mature or as they increase self-sustainability. In case of individualbased lenders, they find that an increase in size and age of the MFI is associated with less outreach, whereas increased profitability is associated with more outreach. This can be interpreted as evidence that mission drift does not occur as a result of the trade-off between profitability and outreach, but simply as a result of an MFI becoming more mature. In contrast, for group-lenders size, age and profitability are not associated with the outreach indicators. Kar (forthcoming), analyzing a panel data set of 409 MFIs in 71 countries between 2003 and 2008 from the Microfinance Information Exchange (MIX) Market database and the Micro-Banking Bulletin (MBB), also finds increased MFI age and size to be associated with a decrease in outreach. He interprets this as a scaling up effect.

Quayes (2012) studies a cross-sectional sample of MFIs retrieved from the MIX Market database. He finds differential results for the impact of financial sustainability on the depth of outreach measured by average loan size depending on the disclosure level of the MFIs: While there is evidence for a trade-off between outreach and financial sustainability for the low-disclosure MFIs, financial sustainability has a positive impact on the depth of outreach for the high-disclosure MFIs.

Mersland/Strom (2009) analyze the effect of corporate governance mechanisms (such as board and CEO characteristics and firm ownership type) as well as competition and regulation on an MFI's financial profitability and outreach to poor clients. Exploiting a sample of 278 MFIs from 60 countries in between 2000 and 2007, they find evidence that financial performance improves with local rather than international directors, internal board auditors and female CEOs. However, there is no evidence for differences in financial performance and outreach between non-profit organizations and shareholder firms. Also, regulation does not seem to have an influence.

Vanroose/D Espallier (2013) analyze the relationship between outreach and performance of MFIs on the one hand, and the development of the traditional financial sector on the other. Their sample covers 1,073 MFIs from all six main developing regions of the world which report to the MIX Market database in the time period from 1997 until 2006. They find that MFIs reach more clients and are more profitable where traditional bank sector development is low. However, in well-developed markets, MFIs give smaller loans indicating they serve poorer borrowers there. Hence, this might be interpreted as evidence that mission drift takes place in underdeveloped banking markets, but not in developed ones. 


\subsection{Conclusion and assessment of the literature}

Existing case studies and cross-sectional analyses do not provide strong evidence for a mission drift in microfinance. While MFIs do seem to move more upmarket as they become more mature, aggregate trends do not point to a substantial reduction in social performance of the microfinance industry as a whole. Moreover, while the outreach of MFI's is negatively correlated with cost-efficiency, the fear of a fundamental tension between profitability and social performance at the level of individual MFIs does not seem warranted. A move upmarket might even be desirable if the corresponding better financial performance and sustainability increase MFIs' capability to reach more low-income customers in absolute terms.

The above findings should mitigate the fears of policy makers that financial support of the microfinance industry may no longer be contributing to their development objectives. Moreover, if commercial microfinance banks do not seem to differ substantially in terms of outreach, the public support to them in the form of subsidized funding or technical assistance seems no less warranted than the support of non-commercial MFIs. Indeed, one may argue that to enhance the sustainability of their interventions, bilateral and multilateral donors should target their support to those institutions which are financially sustainable.

But, in times of budget cuts, how should policy makers justify public support to an industry which seems to be able to achieve the desired social performance without compromising financial performance? Continued public support to commercial microfinance banks can only be justified if they provide social benefits above and beyond those provided by ordinary commercial retail banks. This reasoning points to a first gap in the literature on mission drift in microfinance: Mission drift should not only be measured by social performance of institutions within the microfinance industry, but in the context of expanding the frontier of the financial sector as a whole. As a consequence the social performance of commercial MFIs should not only be compared to that of non-commercial MFIs, but also to that of ordinary retail banks. The comparison of outreach of microfinance banks as opposed to ordinary retail banks is especially important in those developing economies with substantial private foreign direct investment in the banking sector, e.g. Emerging Europe and Latin America. If the retail networks of international banking groups provide banking services to similar households as microfinance banks, then public support of the latter is hardly warranted.

A second shortcoming of the previous literature on mission drift is that the social performance of MFIs is predominantly measured in terms of their lending activity. This is surprising, since academics and practitioners increasingly argue that access to savings and payment services are equally important for poor households to smooth consumption shocks, accumulate productive assets and to reduce their transaction costs of economic exchange (World Bank 2007). As a consequence a comprehensive analysis of mission drift should take into account the range of financial services which MFIs provide to the poor, the accessibility of these services, e.g. the number of branches, ATMs and other points of sale as well as the number and socioeconomic characteristics of households which use these services.

In the next section we summarize results from a recent study which takes a first step at assessing the mission drift of MFIs in a broader financial sector development context. In Brown et al. (2012) we compare the outreach of a major commercial MFI in South-East 
Europe (ProCredit Bank) to the outreach of large retail banks in the same region. We study outreach in terms of the use of bank accounts (and thus the use of savings and payment services) as opposed to household use of loans. Moreover, by analyzing the branchlocation decision of ProCredit Bank over time, we assess the contribution of this commercial MFI to expanding the geographic availability of financial services in the region. Our findings suggest that in South-East Europe this commercial MFI has expanded the frontier of finance. In regions where ProCredit Bank opened a new bank branch the number of households which use bank accounts has increased, and this is especially the case among low-income households and households with informal employment. Moreover, compared to ordinary retail banks, ProCredit is more likely to open new branches in areas with a higher share of low-income households and households which operate in the informal sector.

\section{Microfinance banks and access to finance in South-East Europe}

\subsection{Data sources}

Brown et al. (2012) study the use of bank accounts by households in four South-Eastern European countries: Albania, Bulgaria, Macedonia and Serbia. Household-level information on the use of accounts is taken from the EBRD-World Bank Life in Transition Survey (LITS) which was conducted in 29 countries in 2006 and 2010 as a repeated cross-sectional survey. ${ }^{1}$ In each country, 50 Primary Sampling Units (PSUs) were selected with probability of selection proportional to PSU size. Then twenty households within each PSU were randomly selected, resulting in roughly 1,000 observations per country. ${ }^{2}$ We augment the LITS survey data with geographical information on the location of PSUs. We then match the LITS survey data with geographical information on the branch location of the largest microfinance bank in the region, ProCredit Bank, and with geographical data on the branches of a large retail bank in each country. In each country, we choose the largest, country-wide retail bank for which bank branch location data is publicly available. ${ }^{3} \mathrm{Ap}$ pendix 1 offers a cartographical overview of the locations of PSUs, ProCredit branches and retail bank branches by country in 2006 and 2010 for Serbia.

The dependent variable in all our empirical analyses is Account which indicates whether any member of the household has a bank account. Table 1 shows that in each of the four countries the average use of bank accounts increased strongly between 2006 and 2010. The increase is largest in Macedonia and Albania where the share of households with accounts rose by 38 and 26 percentage points respectively. The increase in Bulgaria (12 percentage points) and Serbia (14 percentage points) is also substantial.

1 For details on the LITS survey see http://www.ebrd.com/pages/research/economics/data/lits.shtml. Beck/ Brown (2011) describe the use of financial services across all surveyed countries.

2 In the 2010 survey wave, 1,500 households were interviewed in Serbia.

3 In Albania and Serbia the chosen retail banks are those with the largest branch network in the respective country. In Macedonia we take the largest bank in terms of assets because the availability of online branch location information is best for this bank. Only in Bulgaria we have to resort to the fourth largest bank in terms of assets because all three larger banks do not provide historical branch location information for 2006 online. 


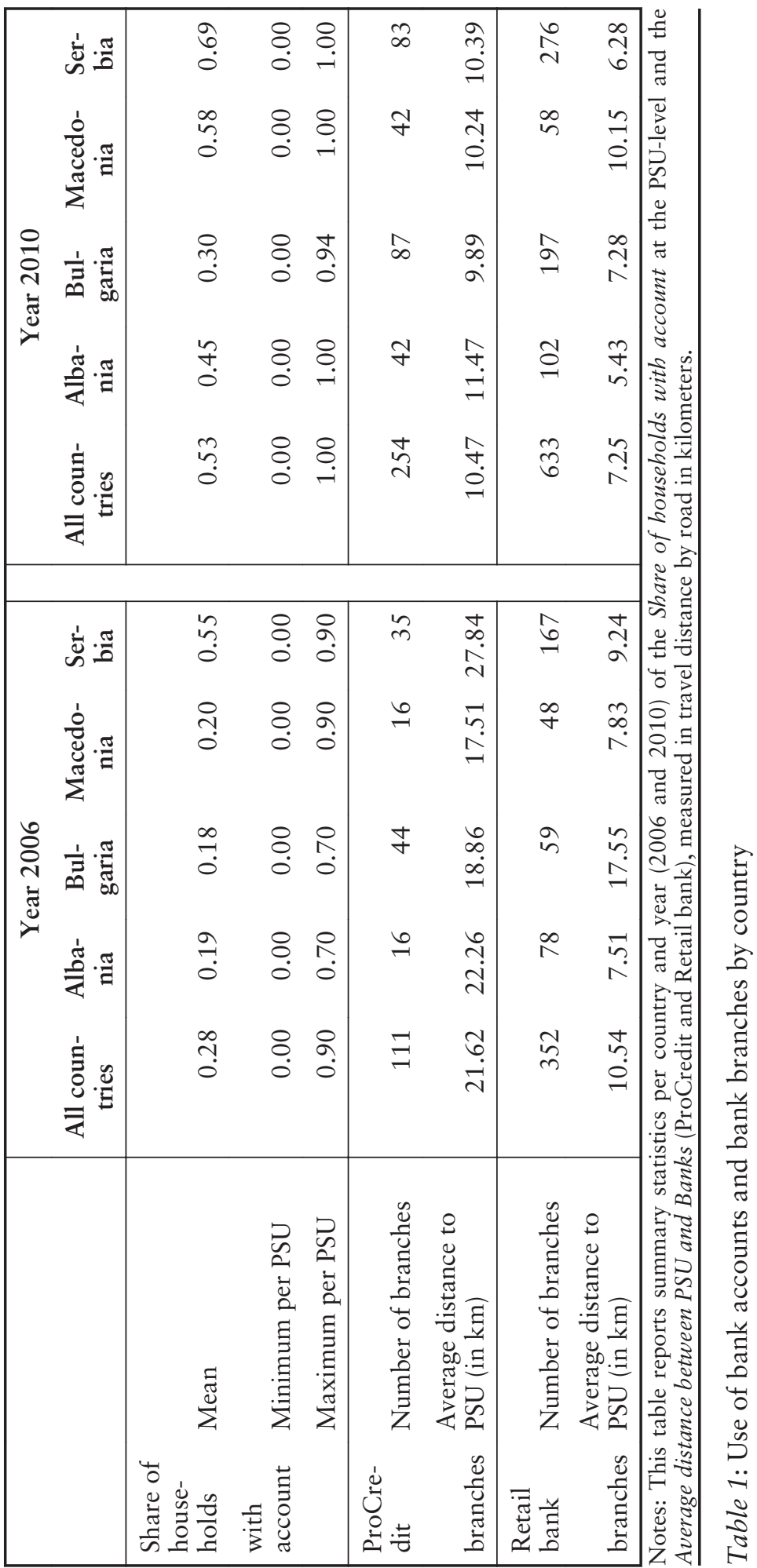


Table 1 also shows that the surge in bank accounts in the region coincides with the expansion of the branch networks of both ProCredit as well as the retail banks. The number of ProCredit branches in our sample increased from 111 in 2006 to 254 in 2010, while the number of retail bank branches increased from 352 to 653. As a consequence of this branch expansion the average travel distance 4 in kilometers between ProCredit branches and surveyed households was reduced from $21.6 \mathrm{~km}$ to $10.5 \mathrm{~km}$. By comparison, the average distance between retail bank branches and surveyed households was reduced from $10.5 \mathrm{~km}$ to $7.2 \mathrm{~km}$. Overall, the larger number of bank branches and the shorter travel distances to households indicate that the retail banks chosen for our analysis have a more comprehensive coverage in the region than ProCredit Bank.

\subsection{Methodology}

The empirical strategy in Brown et al. (2012) exploits the information on the expansion of the branch network of ProCredit Bank in the period 2006-2010. The LITS 2006 and LITS 2010 surveys provide repeated cross-section data, so that we do not observe the same household in 2006 and again in 2010. We therefore generate a synthetic panel by matching households observed in 2006 with similar households observed in 2010. Our matching procedure is based on the proximity of households to branches of ProCredit Bank and the retail bank, proximity to a town (with more than 10,000 inhabitants) as well as on the household income level (low vs. high) and source (informal vs. formal). In order to make household income levels comparable across survey waves, for households observed in 2010 their classification into the low vs. high income groups depends on whether the household's income is below the 2006 country median.

We perform a one-to-one match, i.e. each household in the 2006 LITS survey is matched to one household covered by the LITS 2010 survey. LITS 2006 households that cannot be matched to a LITS 2010 household are dropped and visa-versa. In addition, we drop all observations that have missing values for at least one of the dependent or independent variables. Our matching process generates a total sample of 2,613 potential household pairs for our synthetic 2006-2010 panel.

To identify the impact of new ProCredit Bank branches opened between 2006 and 2010, we drop 1,009 household pairs which were already close to ProCredit Bank branches in 2006. We further consider only household pairs for which the closeness to a retail bank branch does not change between 2006 and 2010. We thus drop 110 household pairs for which closeness to a branch of the retail bank changed in our observation period. This leaves us with a total synthetic panel of 1,494 household pairs in two sub-samples: 477 pairs which are already within a $5 \mathrm{~km}$ radius of a retail bank branch in 2006 as well as 1,017 household pairs which are not within a $5 \mathrm{~km}$ radius of a retail bank branch in 2006 and 2010 .

4 Travel distance, in contrast to linear distance, is the road distance between two locations as obtained from Google maps. In our regression analysis we use travel distance thresholds of five kilometers as opposed to continuous measures of travel distance. This approach reflects the idea that the transaction costs of using a bank account depend on whether a household is within walking, cycling or local public transport distance of a bank branch or not. As robustness tests, we employ different travel distance cutoffs $(10 \mathrm{~km}, 20 \mathrm{~km})$ and find our main results to hold in these specifications as well. 


\section{Results}

Brown et al. (2012) examine three questions in their empirical analysis: Do more households have a bank account in regions where ProCredit Bank has opened a branch compared to locations where it has not opened a branch (Volume effect)? Is ProCredit Bank more likely to open new branches in regions with a higher share of low-income or informal-income households (Location effect)? Does proximity to a ProCredit Bank branch increase the use of bank accounts more for low-income and informal-income households than it does for high-income and formal-income households (Composition effect)?

\subsection{Volume and location effect}

Table 2 presents univariate results for the Volume effect based on a difference-in-difference analysis. For each household pair in our synthetic panel we calculate the change in the use of a bank account between 2006 and 2010. We then compare the average change in account of those pairs for which a new ProCredit branch was opened within a radius of $5 \mathrm{~km}$ to those pairs for which a new ProCredit branch was not opened within a radius of $5 \mathrm{~km}$. This comparison is conducted separately for household pairs which are close to a retail bank and households which are not close to a retail bank.

The first row of Table 2 presents results for household pairs which are close to a retail bank (in 2006 and 2010). The difference-in-difference results suggest that the use of bank accounts increased by 24 percentage points more in regions where a new ProCredit branch was opened in addition to an existing retail bank branch. The second row of Table 2 presents results for household pairs which are not close to a retail bank in 2006 or 2010 . Here, the difference-in-difference estimate shows that the use of bank accounts increased by 41 percentage points more in areas without a retail bank, but where ProCredit Bank opened a new branch between 2006 and 2010 .

The Table 2 results suggest that the volume effect of microfinance branches is significantly lower in regions where a retail bank branch is present compared to regions where the retail bank is not present. However, the results for the subsample where the retail bank is not close have to be interpreted with care because of the low number of pairs which are located in areas with new ProCredit branches (only 30 observations). ${ }^{5}$

To examine the Location effect of microfinance banks, Brown et al. (2012) relate ProCredit Bank's location decision for opening new branches between 2006 and 2010 to the socioeconomic characteristics of the regions (PSU) for which the LITS survey provides information in 2010. We relate the decision of ProCredit Bank to open a new branch within $5 \mathrm{~km}$ of a PSU to the share of low-income households, the share of households with informal income, the share of female-headed households and the share of Muslim households in the PSU. To account for regional economic conditions we control for whether the PSU is close to a regional economic hub (a town of more than 10,000 inhabitants) or not. We further control, for whether the retail bank already had a bank branch in the region in 2006.

5 These univariate results are confirmed in a multivariate first-difference GLS regression that controls for differences in all socioeconomic characteristics within household pairs that are not used in the matching procedure and thus may vary across observation periods (e.g., household size, whether the survey respondent has a university degree or owns a car, computer or mobile phone or has internet access). 


\begin{tabular}{|l|c|c|c|}
\hline & $\begin{array}{c}\text { ProCredit close in } \\
2010\end{array}$ & $\begin{array}{c}\text { ProCredit not close } \\
\text { in 2010 }\end{array}$ & $\begin{array}{c}\text { Difference in } \\
\text { Difference (DiD) }\end{array}$ \\
\hline \multirow{3}{*}{ Retail bank close } & $\begin{array}{c}0.2329 * * * \\
(0.0370)\end{array}$ & $\begin{array}{c}-0.0054 \\
(0.0488)\end{array}$ & $\begin{array}{c}0.2383 * * * \\
(0.0605) \\
(\mathrm{N}=477)\end{array}$ \\
\hline \multirow{3}{*}{ Retail bank not close } & $(\mathrm{N}=292)$ & $(\mathrm{N}=185)$ & $0.4083 * * *$ \\
& $\begin{array}{c}0.5385 * * * \\
(0.1141)\end{array}$ & $\begin{array}{c}0.1302 * * * \\
(0.0202)\end{array}$ & $(0.1264)$ \\
& $(\mathrm{N}=26)$ & $(\mathrm{N}=991)$ & $(\mathrm{N}=1017)$ \\
\hline
\end{tabular}

Notes: This table shows difference-in-difference estimates for account use (Account) for the subsample of those households that are not close to a ProCredit branch in 2006. Households in 2006 are matched with households in 2010 based on observables (ProCredit Bank close in 2006, Retail bank close in 2006, Town close, Low income, Informal income). Standard errors and number of observations (N) are reported in brackets. $* * * * *$ denote significance at the 0.01, 0.05 and 0.10-level. ProCredit close in 2006 (2010) indicates that a ProCredit Bank branch is within $5 \mathrm{~km}$ travel distance to household in 2006 (2010); ProCredit not close in 2010 indicates that there is no ProCredit Bank branch within $5 \mathrm{~km}$ travel distance to household in 2010; Retail bank close (in 2006) indicates that retail bank branch is within $5 \mathrm{~km}$ travel distance to household during the whole observation period (in 2006); Retail bank not close indicates that there is no retail bank branch within $5 \mathrm{~km}$ travel distance to household during the whole observation period; Town close indicates that nearest town with more than 10,000 inhabitants is within $5 \mathrm{~km}$ travel distance to household; Low income indicates that household income is below country mean of 2006; Informal income indicates that survey respondent had no formal labor contract within the past 12 months.

Table 2: Volume effect

The economic rationale behind these variables is that the average socioeconomic conditions in a PSU should affect the location decision of the microfinance bank. As we use average PSU indicators for 2010 we account for the expected future economic conditions in a region which should drive the bank's location decision between 2006 and 2010. We find some evidence for a location effect of this microfinance bank: In those regions where a retail bank is already present, ProCredit Bank was more likely to open a branch where income levels are lower. ${ }^{6}$

Taking the volume and location results together, these effects suggest that the expansion of the ProCredit branch network should have led to a disproportionate increase in the use of bank accounts among low-income households as compared to high-income households. We study the extent of this composition effect in the next section.

\subsection{Composition effect}

Table 3 presents univariate results for the Composition effect based on a difference-indifference analysis. Replicating our analysis in Table 2 we compare the average change in account of household pairs for which a new ProCredit branch was opened between 2006 and 2010 to those pairs for which a new ProCredit branch was not opened. We conduct this comparison again separately for household pairs which are close to a retail bank

6 We also use this location decision regression as the first stage in a two-stage instrumental variables analysis to yield unbiased estimates of the volume effect. We thereby take into account the empirical concern that ProCredit Bank may have opened branches in those regions which experienced a strong aggregate increase in economic activity and use of retail bank accounts and thus that the observed correlation between account use and bank proximity may be due to reverse causality. The analysis does not indicate that our results are driven by reverse causality. 
(Panel $A)$ and households which are not close to a retail bank (Panel B). Within each panel, we now compare the impact of new ProCredit branches for low-income and informalincome households to the impact for high-income and formal-income households.

\begin{tabular}{|c|c|c|c|c|}
\hline & $\begin{array}{l}\text { ProCredit close in } \\
2010\end{array}$ & $\begin{array}{l}\text { ProCredit not } \\
\text { close in } 2010\end{array}$ & $\begin{array}{l}\text { Difference in } \\
\text { Difference }\end{array}$ & $\begin{array}{l}\text { Difference in Differ- } \\
\text { ence in Difference }\end{array}$ \\
\hline Low income & $\begin{array}{c}0.3500 * \cdots \\
(0.0812) \\
(N=100)\end{array}$ & $\begin{array}{c}-0.0303 \\
(0.0592) \\
(\mathrm{N}=33)\end{array}$ & $\begin{array}{c}0.3803 * * * \\
(0.1133) \\
(N=133)\end{array}$ & \multirow{2}{*}{$\begin{array}{c}0.2084 \\
(0.1466) \\
(\mathrm{N}=477)\end{array}$} \\
\hline High income & $\begin{array}{c}0.1720 * * * \\
(0.0465) \\
(\mathrm{N}=192)\end{array}$ & $\begin{array}{c}0.0000 \\
(0.0568) \\
(\mathrm{N}=152)\end{array}$ & $\begin{array}{c}0.1719 * * \\
(0.0727) \\
(\mathrm{N}=344)\end{array}$ & \\
\hline Informal income & $\begin{array}{c}0.2513 * * * \\
(0.0477) \\
(\mathrm{N}=187)\end{array}$ & $\begin{array}{c}0.0169 \\
(0.0589) \\
(\mathrm{N}=118)\end{array}$ & $\begin{array}{c}0.2344 * * * \\
(0.0761) \\
(\mathrm{N}=305)\end{array}$ & \multirow{2}{*}{$\begin{array}{l}-0.0104 \\
(0.1262) \\
(\mathrm{N}=477)\end{array}$} \\
\hline Formal income & $\begin{array}{c}0.2000 * * * \\
(0.0581) \\
(\mathrm{N}=105)\end{array}$ & $\begin{array}{c}-0.0448 \\
(0.0862) \\
(\mathrm{N}=67)\end{array}$ & $\begin{array}{c}0.2448 * * \\
(0.1001) \\
(\mathrm{N}=172)\end{array}$ & \\
\hline
\end{tabular}

Panel A: Retail bank close

\begin{tabular}{|c|c|c|c|c|}
\hline & $\begin{array}{l}\text { ProCredit close in } \\
2010\end{array}$ & $\begin{array}{l}\text { ProCredit not } \\
\text { close in } 2010\end{array}$ & $\begin{array}{l}\text { Difference in } \\
\text { Difference }\end{array}$ & $\begin{array}{l}\text { Difference in } \\
\text { Difference in } \\
\text { Difference }\end{array}$ \\
\hline Low income & $\begin{array}{c}0.5000^{* * *} \\
(0.1890) \\
(\mathrm{N}=8)\end{array}$ & $\begin{array}{c}0.1269 * * * \\
(0.0296) \\
(\mathrm{N}=410)\end{array}$ & $\begin{array}{l}0.3732 \% \\
(0.2139) \\
(N=418)\end{array}$ & \multirow{2}{*}{$\begin{array}{c}-0.0498 \\
(0.2736) \\
(\mathrm{N}=1017)\end{array}$} \\
\hline High income & $\begin{array}{c}0.5556 * * * \\
(0.1451) \\
(\mathrm{N}=18)\end{array}$ & $\begin{array}{c}0.1325^{* * *} \\
(0.0275) \\
(\mathrm{N}=581)\end{array}$ & $\begin{array}{c}0.4230 * * * \\
(0.1583) \\
(\mathrm{N}=599)\end{array}$ & \\
\hline Informal income & $\begin{array}{c}0.5000 * * * \\
(0.1457) \\
(\mathrm{N}=18)\end{array}$ & $\begin{array}{c}0.1294 * * * \\
(0.0238) \\
(\mathrm{N}=734)\end{array}$ & $\begin{array}{l}0.3706 * * \\
(0.1537) \\
(\mathrm{N}=752)\end{array}$ & \multirow{2}{*}{$\begin{array}{c}-0.1221 \\
0.2744 \\
(\mathrm{~N}=1017)\end{array}$} \\
\hline Formal income & $\begin{array}{c}0.625^{* *} \\
(0.1830) \\
(\mathrm{N}=8)\end{array}$ & $\begin{array}{c}0.1323 * * * \\
(0.0385) \\
(\mathrm{N}=257)\end{array}$ & $\begin{array}{l}0.4927 * * \\
(0.0380) \\
(\mathrm{N}=265)\end{array}$ & \\
\hline
\end{tabular}

Panel B: Retail bank not close

Notes: This table shows difference-in-difference estimates for account use (Account) for the subsample of those households that are not close to a ProCredit branch in 2006. Households in 2006 are matched with households in 2010 based on observables (ProCredit Bank close in 2006, Retail Bank close in 2006, Town close, Low income and Informal income). Standard errors and number of observations (N) are reported in brackets. $* * * * * *$ denote significance at the $0.01,0.05$ and 0.10 -level. ProCredit close in 2006 (2010) indicates that a ProCredit Bank branch is within $5 \mathrm{~km}$ travel distance to household in 2006 (2010); ProCredit not close in 2010 indicates that there is no ProCredit Bank branch within $5 \mathrm{~km}$ travel distance to household in 2010; Retail bank close (in 2006) indicates that retail bank branch is within $5 \mathrm{~km}$ travel distance to household during the whole observation period (in 2006); Retail bank not close indicates that there is no retail bank branch within $5 \mathrm{~km}$ travel distance to household during the whole observation period; Town close indicates that nearest town with more than 10,000 inhabitants is within $5 \mathrm{~km}$ travel distance to household; Low (High) income indicates that household income is below (above) country mean of 2006; Informal income indicates that survey respondent had no formal labor contract within the past 12 months, whereas Formal income indicates that survey respondent had a formal labor contract within the past 12 months.

Table 3: Composition effect 
The results in Table 3, Panel A confirm that in regions where a retail bank is already present new microfinance bank branches are associated with a stronger increase in the use of bank accounts among low-income households. The reported estimates suggest that a new ProCredit branch increases the use of bank accounts among low-income households by 35 percentage points while the corresponding effect for high-income households is only 17 percentage points. By contrast, there seems to be a much smaller difference in the impact of new ProCredit branches on informal-income households (25 percentage points) as opposed to formal-income households (20 percentage points).

The results in Table 3, Panel B suggest that in regions where a retail bank is not present new microfinance bank branches are associated with a similar effect among low-income households (50 percentage points) and high-income households (56 percentage points). There seems to be a stronger difference in the impact of new ProCredit branches on informal-income households (50 percentage points) as opposed to formal-income households (63 percentage points). Actually, we observe a stronger increase in the use of bank accounts among high-income and formal-income households when a retail bank is not present.

Due to the low number of observations in many cells in Panel $B$ our results for the subsample of pairs which are not close to a retail bank should be interpreted with care. Nevertheless, this analysis yields an interesting finding: The relative impact of a microfinance bank on low-income households is stronger in regions where a retail bank is present compared to regions where the retail bank is not present. The intuition behind this result is that in the former regions high-income households already have access to bank accounts through the retail bank, so that the incremental effect of the microfinance bank is strongest for low-income households. By contrast, in regions without a retail bank both high-income and low-income households benefit from the entry of the microfinance bank. ${ }^{7}$ This result can also be interpreted as indirect evidence that commercial microfinance banks, such as ProCredit Bank, provide high-quality banking services that are attractive and suitable for a wide range of customers, and not services of inferior quality for poor people. Consequently, the impact of such microfinance banks might not only lie in their ability to expand the frontier of finance but also in setting high quality standards in providing services to the lower end of the market.

\section{Conclusions}

The commercialization of microfinance and the possibly resulting mission drift of MFIs away from their original target groups of poor, female, and rural borrowers towards more profitable but less deprived customers has been the subject of much debate among practitioners, policy makers and academics. The existing empirical evidence suggests that mission drift in microfinance should not worry policy makers. While MFIs do seem to move more upmarket as they become more mature, aggregate trends do not point to a substantial reduction in social performance of the microfinance industry as a whole. Even at the level of individual MFIs there does not seem to be a fundamental tension between financial and social performance.

7 Again, we find confirmation for our main results in a multivariate regression and when taking into account the location decision of the bank in the first stage. 
The above findings suggest that to enhance the sustainability of their interventions, bilateral and multilateral donors should target their support to those institutions which are financially sustainable. But, in times of budget cuts, how should policy makers justify public support to an industry which seems to be able to achieve the desired social performance without compromising financial performance? Continued public support to commercial microfinance banks can only be justified if they provide social benefits above and beyond those provided by ordinary commercial retail banks. This seems to be the case. In a recent study we use household-level survey data for four countries in South-East Europe in 2006 and 2010 to show that microfinance banks do expand the frontier of finance as compared to ordinary retail banks. Holding constant the presence of ordinary retail banks, we find that microfinance banks are more likely to open new branches in regions where there is a higher share of deprived (e.g. low-income and informally employed) households. In regions where microfinance banks open new branches (compared to those where they do not) we see a surge in the use of bank accounts, especially among low-income households.

These new empirical findings have implications for policy makers who aim to foster access to financial services by supporting commercial microfinance banks. They confirm that public investment in microfinance banks seems warranted even in emerging markets that are served by relatively large retail branch networks of international banking groups.

\section{References}

Armendáriz de Aghion, B./Morduch, J. (2005): The Economics of Microfinance, Cambridge, MA.

Beck, T./Brown, M. (2011): Which Households use Banks? Evidence from the Transition Economies, ECB Working Paper No. 1295.

Brown, M., et al. (2012): Microfinance Banks and Household Access to Finance, University of St. Gallen, Working Paper.

Charitonenko, S., et al. (2004): Commercialization of Microfinance - Perspectives from South and Southeast Asia, Asian Development Bank, Manila, under http://www.adb.org/sites/default/files/p ub/2004/micro_SE.pdf, retrieved on 10.9.2012.

Clarke, G., et al. (2009): Bank Privatization in Sub-Saharan Africa: The Case of Uganda Commercial Bank, in: World Development, Vol. 37, No. 9, pp. 1506-1521.

Cull, R., et al. (2007): Financial Performance and Outreach: A Global Analysis of Leading Microbanks, in: The Economic Journal, Vol. 117, pp. 107-133.

Cull, R./Spreng, C. (2011): Pursuing Efficiency while Maintaining Outreach: Bank Privatization in Tanzania, in: Journal of Development Economics, Vol. 94, pp. 254-261.

Dehejia, R., et al. (2012): Do Interest Rates Matter? Credit Demand in the Dhaka Slums, in: Journal of Development Economics, Vol. 97, No. 2, pp. 437-449.

Deutsche Bank Research (2007): Microfinance: An Emerging Investment Opportunity, December 19, 2007, under http://www.microrate.com/media/docs/investment/deutsche-bank-microfinancean-emerging-investment-opportunity-dec-07.pdf, retrieved on 10.9.2012.

Hermes, N., et al. (2011): Outreach and Efficiency of Microfinance Institutions, in: World Development Volume, Vol. 39, No. 6, pp. 938-948.

Hermes, N./Lensink, R. (2011): Microfinance: Its Impact, Outreach, and Sustainability, in: World Development, Vol. 39, No. 6, pp. 875-881.

$\mathrm{Kar}$, A. (forthcoming): Mission drift in microfinance: are the concerns really worrying? Recent cross-country results, in: International Review of Applied Economics, forthcoming. 
Karlan, D./Zinman, J. (2008): Credit Elasticities in Less-Developed Economies: Implications for microfinance, in: American Economic Review, Vol. 98, No. 3, pp. 1040-1068.

Khan, A. (2008): Commercialization of Microfinance - Is the Sector Losing its Identity by Evading its Original 'Social Service' Responsibility, in: Social and Environmental Accountability Journal, Vol. 28, No. 2, pp. 78-90.

Mersland, R./Strom, R. (2009): Performance and Governance in Microfinance Institutions, in: Journal of Banking \& Finance, Vol. 33, No. 4, pp. 662-669.

Mersland, R./Strom, R. (2010): Microfinance Mission Drift?, in: World Development, Vol. 38, No. 1, pp. 28-36.

Mersland, R., et al. (2011): The Impact of International Influence on Microbanks' Performance: A Global Survey, in: International Business Review, Vol. 20, No. 2, pp. 163-176.

Morduch, J. (1999): The Microfinance Promise, in: Journal of Economic Literature, Vol. 37, No. 4, pp. 1569-1614.

New York Times (2008): Microfinance's Success Sets Off a Debate in Mexico, 5 April 2008, under http://www.nytimes.com/2008/04/05/business/worldbusiness/05micro.html? pagewanted=print, retrieved on 10.9.2012.

Quayes, S. (2012): Depth of Outreach and Financial Sustainability of Microfinance Institutions, in: Applied Economics, Vol. 44, No. 26, pp. 3421-3433.

Roberts, $P$. (forthcoming): The Profit Orientation of Microfinance Institutions and Effective Interest Rates, in: World Development.

Robinson, M. (2001): The Microfinance Revolution: Sustainable Banking for the Poor, Washington, DC: The World Bank, under http://www-wds.worldbank.org/external/default/ WDSContentServ er/WDSP/IB/2007/08/23/000310607_20070823152333/Rendered/PDF/232500v 10REPLA1808 2134524501PUBLIC1.pdf, retrieved on 10.9.2012.

Tchakoute-Tchuigoua, H. (2010): Is There a Difference in Performance by the Legal Status of Microfinance Institutions?, in: The Quarterly Review of Economics and Finance, Vol. 50, pp. 436442.

Vanroose, A./D`Espallier, B. (2013): Do Microfinance Institutions Accomplish their Mission? Evidence from the Relationship between Traditional Financial Sector Development and Microfinance Institutions' Outreach and Performance, in: Applied Economics, Vol. 45, No. 15, pp. 1965-1982.

World Bank (2007): Finance for All? Policies and Pitfalls in Expanding Access, Washington, DC.

Yunus, M. (2011): Sacrificing Microcredit for Megaprofits, 14 January 2011, under http://www.nyti mes.com/2011/01/15/opinion/15yunus.html?hp, retrieved on 4.9.2012. 


\section{Serbia, 2006}

ProCredit, Komercijalna and PSU

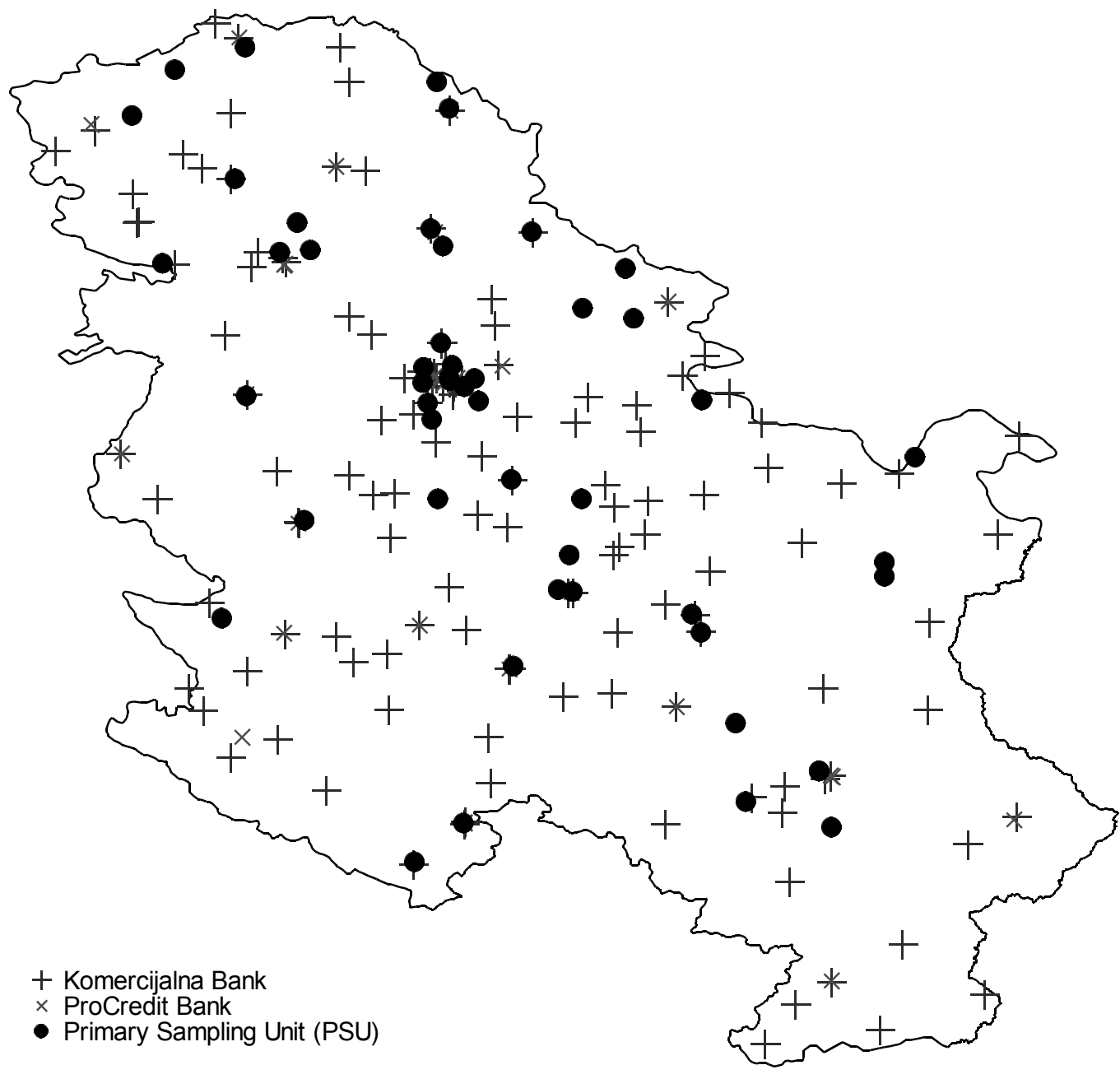




\section{Serbia, 2010}

ProCredit, Komercijalna and PSU

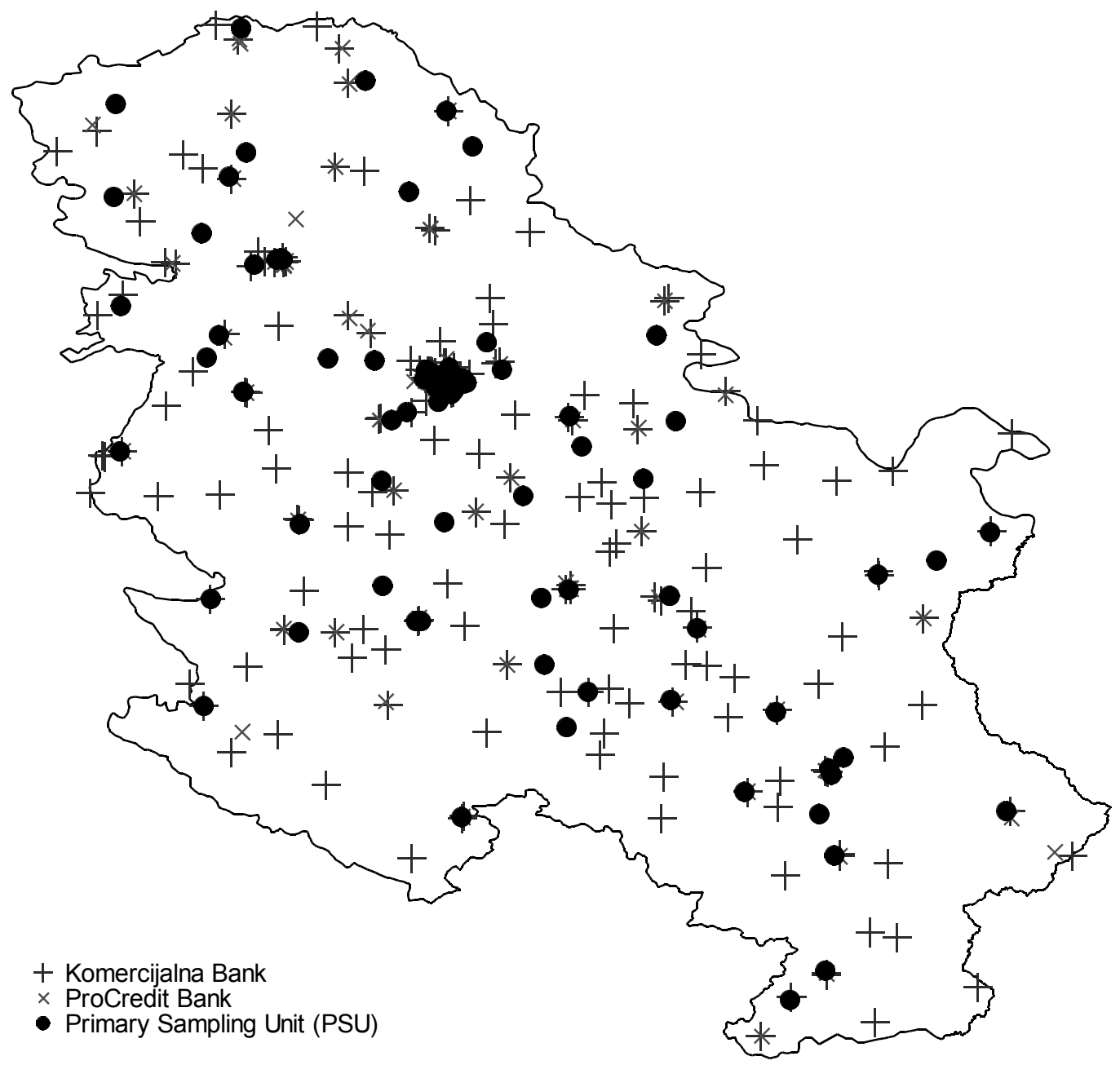

Appendix 1: Serbia: Bank and household locations in 2006 and 2010 
Martin Brown, Dr., is Full Professor of Banking at the University of St. Gallen and Member of the Board of the Swiss Institute for Banking and Finance s/bf-HSG and of the School of Finance.

Address: Swiss Institute of Banking and Finance s/bf-HSG at University of St.Gallen, Rosenbergstrasse 52, CH-9000 St. Gallen, Tel.: +41 (0)71/224-70-62, E-mail: martin.brown@unisg.ch

Benjamin Guin, Dipl.-Volksw., is a PhD candidate and Research Assistant at the Swiss Institute for Banking and Finance s/bf-HSG of University of St. Gallen.

Address: Swiss Institute of Banking and Finance s/bf-HSG at University of St.Gallen, Rosenbergstrasse 52, CH-9000 St.Gallen, Tel.: +41 (0)71/224-70-41, E-mail: benjamin.guin@unisg.ch

Karolin Kirschenmann, Dr., is Assistant Professor of Finance at Aalto University in Helsinki.

Address: Aalto University, School of Business, Department of Finance, PO Box 21220, 00076 Aalto, Finland, Tel.: +358 (0)50/591-9589, E-mail: karolin.kirschenmann@aalto.fi 